\title{
Ольга УШАКОВА
}

\section{ЖУРНАЛ “CRITERION” О РУССКОЙ РЕВОЛЮЦИИ И КОММУНИЗМЕ}

\begin{abstract}
Аннотация: Статья посвящена анализу рецепции Русской революции 1917 г. и ее последствий в западном культурном контексте, в кругах, связанных с «интернациональным» модернизмом. Объектом исследования являются материалы на революционную тематику в журнале «Criterion» (1922-1939): поэзия, художественная проза, аналитические эссе, публицистическая полемика, редакционные комментарии, рецензии, обзоры периодики и т.п. Особое внимание уделяется восприятию Русской революции в работах редактора журнала Т.С. Элиота. В частности, рассматривается образ революции как часть мифологемы «бесплодной земли» (поэма «Бесплодная земля», опубликованная в первом выпуске журнала, 1922), пародийное описание коллективной паники в ожидании революционных событий в рассказе «Накануне: Диалог» (1925), анализ событий в России с геополитической точки зрения в редакторских комментариях, полемика о коммунизме на рубеже 1920-30 гг. («Мистер Барнс и мистер Роуз») и др. Автор статьи обращается к ряду имен и текстов, формировавших представления о событиях в России после 1917 г. В числе прочего рассматриваются публикации Джона Курноса, одного из «русских» авторов журнала.

Ключевые слова: Русская революция, коммунизм, журнал «Criterion», Т.С. Элиот, Джон Курнос, В.И. Ленин, Л.Д, Троцкий, русская литература, интернациональный модернизм.
\end{abstract}

() 2017 Ольга Михайловна Ушакова (доктор филол. наук, профессор; Тюменский государственный университет, Россия) olmiva@ rambler.ru 


\title{
Olga USHAKOVA
}

\section{THE RUSSIAN REVOLUTION AND COMMUNISM IN “THE CRITERION”}

\begin{abstract}
The article aims to outline the reception of the Russian Revolution of 1917 and its consequences in the Western cultural context, first and foremost, in the circles connected to the "international" modernism. The author turns to the materials on the Revolution in the journal The Criterion (1922-1939) including poetry, fiction, analytical essays, public discussions, editorial commentaries, reviews, reviews of periodicals, etc. Particular attention is paid to the perception of the Russian Revolution in the works of the journal editor, T.S. Eliot. The image of the Russian Revolution is considered as a part of the mythologeme of the "waste land" (the poem "The Waste Land" was published in the first issue of the journal in 1922). The other issues under consideration are the parodic narration of the collective panic and the expectations for the revolutionary events in the story "On the Eve: Dialogue" (1925), the analysis of the Russian cataclysms from the geopolitical point of view in The Criterion's editorial commentaries, the polemics on Communism at the turn of the 1920-30-s ("Mr. Barnes and Mr. Rose"), etc. The author of the article summarizes a number of names and texts producing ideas and forming the representations of Russia after 1917. One of the topics deals with the works by John Cournos, a "Russian" author of the journal.

Keywords: Russian Revolution, Communism, journal "Criterion", T.S Eliot, John Cournos, V.I. Lenin, L.D. Trotsky, Russian literature, international modernism.
\end{abstract}

(C) 2017 Olga M. Ushakova (Doctor Hab. of Philology, Professor; University of Tyumen, Russia)olmiva@rambler.ru 
Вопрос о значении Русской революции 1917 г. («Великой октябрьской социалистической революции») как глобального события до сих пор не утратил своего значения и актуальности, так как даже столетие спустя представляет собой масштабное поле для дискуссий с полярными полюсами, обширными лакунами, дремучими дебрями и горячими точками. В данной статье предлагается обратиться к проблеме восприятия Русской революции в западной культуре ("Russian Revolution" - наиболее часто употребляемое название этого исторического события в англоязычной среде), прежде всего, в тех кругах, которые так или иначе были связаны с «международным» модернизмом (international Modernism). Каким образом Русская революция повлияла на британское общественное мнение, какие точки зрения и интерпретации бытовали и превалировали, в каких формах видные деятели культуры обсуждали революцию и Советскую Россию и т.п.? Объектом исследования является журнал “Criterion” (1922-1939), редактором которого был T.C. Элиот (T.S. Eliot, 1888-1965), известный своими консервативно-«охранительными», «реакционными» политическими взглядами и являющийся в то же время создателем новых «революционных» художественных форм и концепций.

В отечественном литературоведении сложилась достаточно основательная традиция изучения левого, пролетарского, просоветского направления революционной рефлексии в Британии и США. Так, например, первыми отечественными рецензентами «культовой» книги Джона Рида (John Reed, 1887-1920) «Десять дней, которые потрясли мир» (Ten Days That Shook the World, 1919; pус. пер. 1923) были В.И. Ленин и Н.К Крупская: «Иностранцы иначе пишут о России. Они или вовсе не понимают совершающихся событий, или берут отдельные факты, не всегда типичные, и их обобщают» [Крупская 1987, с.28]. Библиографический справочник «Американская литература в русских переводах и критике. Библиография 1776-1975» В.А. Либман фиксирует большое количество работ советских исследователей, посвященных изучению различного рода литературной рефлексии на темы революции и советского строя в США (первые отечественные отклики на книгу Рида датируются 1920 г. [Либман 1977, с. 214] и становятся отправной точкой регулярного обращения к данной теме вплоть до конца 1980-х). Сверившись с соответствующими разделами библиографии, не сложно констатировать, что внимание нашей критики сосредоточено в основном на материалах апологетического характера. В то же время противоположная или «иная» точка зрения на Русскую революцию изучена меньше, хотя репрезентирована в многочисленных и разнообразных источниках. 
Т.С. Элиот, американский ровесник Рида и его соученик по Гарварду (оба будущих литератора поступили в университет в 1906 г.), также не смог обойти или не «заметить» тему Русской революции. Жизненный путь, литературная карьера и судьба художников, выходцев из американской буржуазной элиты, складывались и развивались в одном и том же времени, но в абсолютно разных идеологических и эстетических пространствах. Элиот, становится редактором интеллектуального общеевропейского «толстого» журнала в Лондоне в то время (1922), как его ровесник и «однокашник» уже навечно упокоился у Кремлёвской стены в Москве (1920). Показательно, что «поборник» элитарного «чистого» искусства не смог уйти от обсуждения насущных вопросов современности, включая события в России, революцию, пролетариат, марксизм и труды Л.Д. Троцкого.

В журнале "Criterion", задуманном Элиотом как международное «общеевропейское» периодическое издание, были представлены различные виды высказываний, посвященных рецепции Русской революции. Революционная тематика отражена в публикациях разного рода: поэзии, художественной прозе, аналитических эссе, публицистической полемике, редакционных комментариях, рецензиях, обзорах и т.п. В них представлены самые разные ракурсы и оптика: от изображения карамазовской «азиатской» стихии «заката Европы» и обывательских страхов перед «гадаринскими свиньями» до размышлений о реакционном/революционном и регрессивном/прогрессивном характере коммунизма и фашизма как актуальных идеологических доктрин и общественнополитических практик. Широким является и спектр репрезентированных политических позиций, методологических и художественных подходов к освоению феномена Русской революции как события глобального масштаба. В целом, «русские» страницы в журнале “Criterion" предлагают читателям и исследователям различные сюжеты, повороты и ракурсы русской темы в общеевропейском и шире - международном формате. Элиот как редактор журнала предоставлял слово авторам различной политической окраски и идеологических пристрастий, что делает "Criterion" весьма репрезентативным и полновесным ресурсом для понимания объективной интеллектуальной и художественной панорамы эпохи.

Журнал "Criterion", предусмотрительно переизданный в полном объёме в конце 1960-х гг. в издательстве "Faber \& Faber", не случайно до сих пор привлекает внимание исследователей не только творчества Элиота, но и представителей других направлений и специальностей. Элиот, подготовивший переиздание жур- 
нала, заметил в своем предисловии: «Я думаю [...], что семнадцать томов “Criterion” все вместе представляют ценную летопись интеллектуальной жизни периода между двумя войнами» [Eliot 1967: i]. Некоторые аспекты, касающиеся рецепции российской истории и культуры, уже исследовались в работах зарубежных и отечественных литературоведов. В частности, этим вопросам посвящены статьи британского ученого Дэвида Эйрза «“Criterion” и коммунизм» (The Criterion and Communism [Ayers (a) 2011]), «Джон Курнос и политика русской литературы в "Criterion"» (John Cournos and the Politics of Russian Literature in 'The Criterion" [Ayers (b) 2011]), а также публикации О.М. Ушаковой «Т.С. Элиот - издатель: Россия и русская культура на страницах журнала "Крайтерион"» [Ушакова 2011], «Россия и русская культура в "Criterion", 1922-1939» (Russia and Russian Culture in "The Criterion", 1922-1939 [Ushakova 2012]). В этих работах рассматриваются такие вопросы, как интерпретация Элиотом идей Л.Д. Троцкого [Ayers (a) 2011], вклад крайтерионовских публикаций русско-американского литератора Джона Курноса в расширение представлений англоязычных читателей о культурной ситуации в СССР [Ayers (b) 2011], динамика издательской политики русского направления журнала «от Дягилева до Сталина» [Ушакова 2011; Ushakova 2012] и т.п.

Журнал "Criterion" появился в то время, когда реакция на события в России, включая выражение восторга и ужаса, утратила свой непосредственный эмоциональный характер и остроту сиюминутного переживания и сопричастности к происходящему. «Hail! The Russian Revolution. Конференция трудовых, социалистических и демократических организаций Великобритании приветствует Русскую Революцию!» [Koteliansky Papers 1917] — подобное воодушевление, особенно отличающее документы периода между Февральской и Октябрьской революциями, становится в начале 1920-х все менее актуальным, и события 1917 г. в России начинают интерпретироваться в аналитическом ретроспективном планах через призму «смысла истории», в глобальном общеполитическом ракурсе. В первом номере журнала "Criterion" (октябрь 1922 г.), где ставка делалась именно на русскую тему (дань общеевропейскому «культу Достоевского») и главной сенсацией которого была первая публикация плана романа «Житие великого грешника» Ф.М. Достоевского, тема Русской революции проблематизируется в контексте «достоевщины» и «заката Европы».

В первом номере также была опубликована поэма Элиота «Бесплодная земля», в поэтическом континууме которой Русская революция предстает как часть мифологемы бесплодной земли и 
угроза европейской культуре. В пятой части поэмы «Что сказал гром» (строки 366-376) разворачивается панорама распада и крушения основных центров западной цивилизации под натиском наступающих орд: «Что за звук высоко в небе // Материнское тихое причитанье // Что за орды лица закутав роятся // По бескрайним степям спотыкаясь о трещины почвы // В окружении разве что плоского горизонта // Что за город там над горами // Разваливается в лиловом небе // Рушатся башни // Иерусалим Афины // Александрия // Вена Лондон // Призрачный» (перевод А. Сергеева [Элиот 2014, с. 37]). На русский, «карамазовский» след в этом эпизоде указывает сам автор в своих комментариях к поэме, отмечая, что этот образ - аллюзия к книге Г. Гессе «Взгляд в хаос», опубликованной в английском переводе в июне 1922 г. в американском журнале "Dial" по рекомендации самого Элиота (в этом же американском журнале в ноябрьском номере будет опубликована «Бесплодная земля»). Элиот в заметках к соответствующим строкам «Бесплодной земли» цитирует Гессе: «Уже половина Европы, уже по меньшей мере половина Восточной Европы на своем пути к Хаосу продвигается в опьянении и священном безумии к краю бездны и поет, поет опьяненно и экстатично, как пел Дмитрий Карамазов. Оскорбленный бюргер смеется над этими песнями, святой и духовидец слушают их плач» (пер. В.М. Толмачева) [Элиот 2014 , с. 51]. Элиот разделяет позицию части западного интеллектуального сообщества, увидевшей в Русской революции не прогрессивное политическое событие, а начало распада многовекового цивилизационного уклада, высвобождение темной первозданной материи, дионисийского стихийного начала.

У русского читателя «Бесплодной земли» неизбежно возникает еще одна поэтическая ассоциация, являющаяся неотъемлемой частью европейского революционного поэтического контекста, отзвуком «музыки революции»/«материнского плача» - это «Двенадцать» и «Скифы» (1918) А.А. Блока. Представляется достоверным, что Элиот читал прозаический перевод «Скифов» в “Times Literary Supplement”, поэтому образ «орд» (“hooded hordes”) органично вписывается в современный поэтический и философский контекст. Поэма «Двенадцать» на Западе сразу же после публикации приобрела репутацию «революционной» и «большевистской» ${ }^{1}$. В предисловии к первому книжному изданию поэмы на английском языке переводчик К.Э. Бехофер-Робертс (C.Е. Bech-

\footnotetext{
${ }^{1}$ См. о первых британских и американских переводах и откликах обстоятельную статью А. Паймана «Блок в английском и американском литературоведении» [Пайман 1993]).
} 
hofer) замечает: «“Двенадцать” Блока - первый шедевр большевистской литературы. В своей поэме Блок стремится прорваться сквозь убогость и ханжество большевизма к тем импульсам и страстям, которые способствовали его перерастанию во всемирное движение, поставившее под свои знамена тысячи энтузиастов во многих странах» [Blok 1920: v]. Этот перевод «Двенадцати» (опубликован в Лондоне в 1920 г. с иллюстрациями М. Ларионова) вряд ли мог пройти мимо Элиота, в том числе, и потому, что Бехофер вращался в тех же кругах модернистской богемы, что и Элиот, у них были общие знакомые (Б. Анреп, К. Мэнсфилд и др.), общие интересы (например, русские мистики), а иллюстратор поэмы был автором декораций к балетам С. Дягилева (страстным поклонником которых Элиот являлся); о «балетной» деятельности Ларионова специально сообщалось в предисловии переводчика [Blok 1920: ix]. Можно сказать, что эта книга отвечала всем требованиям бытующей художественной моды и в то же время представляла новое для европейской культуры явление - «большевистскую», революционную по духу и форме поэзию. Не исключено, что новая поэтика могла привлечь профессиональное внимание будущего классика модернистского поэтического эпоса, что отразилось в его собственных произведениях этого периода. Сходство «Бесплодной земли» и «Двенадцати» отмечалось уже современниками Элиота, и не было опровергнуто редактором “Criterion”, в котором в 1932 г. была опубликована статья «Значение Александра Блока» (The Position of Alexander Blok): «Отражение этого настроения проявилось в поэме «Двенадцать», написанной в январе 1918 г. В свое время признанная шедевром, она звучала ежедневно перед толпами слушателей и переведена на большинство европейских языков. Она не похожа не другие произведения Блока и является бесспорным шедевром. По своим поэтическим принципам она напоминает «Бесплодную землю», хотя отличается меньшим уровнем символизма и более выраженным повествовательным характером» [Bowra 1932: 435].

Скифско-карамазовский поэтический образ наступающей с Востока «тьмы» орд, траектория нашествия которых в одном из черновых вариантов «Бесплодной земли» привязана к конкретному географическому пространству («польским равнинам»), претворится позднее в элиотовскую геополитическую идею Русской революции как сугубо восточного, азиатского, примитивного архаического явления: "Who are those hooded hordes swarming // Over Polish plains, stumbling in cracked earth" [The Waste Land 1971, pp. 74-75]. В черновике слово "Polish" («польские») зачеркнуто с исправлением сначала на "perished” («затерянные», «гиблые»), 
потом на "endless" («бескрайние»). Большевистская Россия воспринимается Элиотом как часть чуждого, иного, враждебного «азиатского» пространства и в то же время не является частью «другого Востока», «Индии духа», несущих надежду духовного просветления.

Идея русско-азиатской угрозы продолжает развиваться и приобретает в работах Элиота все более идеологически четкие контуры. В письме С. Райсу от 1 октября 1923 г. редактор "Criterion", отвечая на предложение корреспондента подготовить для журнала материалы о «влиянии Азии на Европу и Европы на Азию», уже в критическом разрезе объединяет имена Достоевского и Гессе как носителей «ориентального», азиатского сознания, несущего угрозу разрушения европейской культурной традиции: «Поскольку немцы являются очень истерической расой, то они всегда выбирают самые истерические и нездоровые аспекты восточного искусства и мысли, а в последние годы они все больше и больше поворачиваются на Восток, и все больше и больше в сторону России, по-видимому, прозрев после фиаско Раппальского договора. Если германо-азиатское влияние проникнет в Западную Европу, то результатом этого может быть ослабление тех европейских традиций, без следования которым мы можем впасть в состояние варварства подобное тому, в котором пребывают Америка или Россия. Мой друг Герман Гессе, чей талант я безмерно ценю, являет собой пример такого рода ориентализации, в отношении которой я питаю страх, и у меня даже был соблазн написать чтолибо критическое в адрес его книги [...] и писателя, которого он так высоко ценит - Достоевского» [The Letters of T.S. Eliot 2009: 230]. В редакторском «Комментарии» за август 1927 г. Элиот привлекает внимание к геополитической опасности, исходящей от России, обращаясь все к той же мифологеме Русской революции как проявлению варварского ориентализма: «...самым значительным событием военного времени стала Русская революция. Именно Русская революция заставила взглянуть на положение Европы (говоря словами Валери) как на небольшой, изолированный мыс на западной оконечности азиатского континента» [Eliot 1927: 98].

Образ высвобождения темной, архаической, примитивной энергии, связанный с выходом на историческую арену низовых социальных слоев («Двенадцать»), наступления со стороны Востока темной разрушительной стихии («Скифы», «Бесплодная земля»), осмысленная в поэтической форме, найдет также свое рациональное выражении в идее о «реакционном» и популистском характере Русской революции, высказанной в дискуссии о 
фашизме и коммунизме, развернувшейся в “Criterion" на рубеже 1920-1930-х гг. В статье 1929 г. «Мистер Барнс и мистер Роуз» (Mr. Barnes and Mr. Rowse) Элиот, рассуждая о «выхолощенном», интеллектуально тривиальном характере доктрин фашизма и коммунизма, замечает, что «революционная идея требует реорганизации сознания», а «ни фашизм, ни коммунизм не являются новыми или революционными именно как идеи» [Eliot 1929: 691], поэтому в силу своей банальности и «привычности» они так хорошо усваиваются массовым сознанием (“absorbed by popular mind”) [Eliot 1929: 682]. Любопытно, что в этой сугубо политической полемике можно заметить отзвуки столь популярных в модернистской среде ритуалистических теорий, касающихся архаического коллективного бессознательного и получивших здесь новое идеологическое измерение (принесение кровавой жертвы ради будущего). В этом ритуалистическом ракурсе Русская революция является не столько актом сознательной политической воли, pеализацией идей западных интеллектуалов, социалистов-марксистов, сколько высвобождением примитивной темной коллективной энергии, дремлющей в глубинах европейской цивилизации. Русская революция в этом контексте воспринимается не так, как декларировалось в ленинских работах (погрешность в теории К. Маркса и Ф. Энгельса, предсказывавших социалистическую революцию в индустриально развитой державе), а трансформация существующего порядка вещей или даже возврат к прошлому с его мифологическим аграрным сознанием, что становилось очевидным части западных интеллектуалов по мере развития и реализации идей коммунизма в СССР. В работе «Мистер Барнс и мистер Роуз» Элиот, основываясь на опыте наблюдения десятилетнего послереволюционного развития СССР, рассуждает о том, что революционные преобразования все более явно обнаруживают свой рутинный регрессивный характер, представляя собой «трансформацию уже существовавшей системы» [Eliot 1929: 690].

Страх разрушения и крушения европейской цивилизации становится темой еще одной «революционной» публикации в “Criterion", решаемой скорее в ироническом и пародийном ключе. В 1925 г. в январском номере журнала был напечатан рассказ «Накануне. Диалог» (On the Eve. A Dialogue). В отличие от уже упомянутых работ, это скорее игривая реплика на тему Революции. Название рассказа отсылает читателя к роману И.С. Тургенева «Накануне» и, соответственно, к теме русского нигилизма, столь популярной на английской почве ${ }^{2}$. Фабула отражает харак-

${ }^{2}$ См. об этом статью «Русский нигилист как герой английской литературы ХІХ-XXI вв.» [Ушакова 2016]. 
терный для послереволюционных лет страх обывателя перед новыми политическими потрясениями, для которого русская революция, анархизм, нигилизм, коммунизм относятся к единому синонимическому ряду, как это выражается в их диалогах.

Одна из интриг этой публикации связана с вопросом об авторстве. К. Сеймур-Джоунз (Carole Seymour-Jones), автор книги «Расцвеченная тень» (Painted Shadow), посвященной Вивьен, первой жене Элиота, утверждает, что сочинителем является сама Вивьен [Seymour-Jones 2002, pp. 354-355]. Сеймур-Джоунз характеризует «Накануне» как автобиографический эскиз Вивьен, появившийся в “Criterion" под именем Т.С. Элиота, отмечая характерный для письма жены Элиота стиль и следы редактирования супруга. Известно, что Вивьен Хейвуд-Элиот (Vivien Haigh-Wood, 1888-1947) не обошла мода на русофильство, она была страстной почитательницей всего русского: от балета и литературы до революционных идей. Сеймур-Джонс упоминает о ее радикальных политических взглядах (спектр симпатий простирался от большевизма до фашизма) и про «ее восхищение Лениным, чьи волнующие и горькие революционные песни доводили ее до слез на встречах Общества любителей кино, в которое она входила». Проблема авторства, реальная биографическая коллизия, отраженная в сюжете, прототипы главных героев, конкретные исторические события английской политической и общественной жизни, на фоне которых разворачиваются разговоры персонажей «Накануне», могут быть предметом специального исследования. В рамках нашей статьи интерес представляют те аспекты, которые непосредственно связаны с темой Русской революции. К ним можно отнести «революционно» маркированные аллюзии к произведениям русских писателей, рассуждения персонажей о России, изображение новых жизненных и социальных реалий и, наконец, создание атмосферы панического страха перед возможным повторением русского сценария в Англии.

Очевидной отсылкой к тематике, связанной с коренными историческими переменами и революционным контекстом, является самоназвание рассказа «Накануне», вызывающее конкретные литературные ассоциации не только в русском, но и западном культурном сознании. Эдвард Гарнетт, автор первой британской монографии о Тургеневе («Тургенев», с предисловием Джозефа Конрада, опубл. в Лондоне издательством W. Collins Sons \& Co. LTD в 1917 г.), рецензию на которую Элиот опубликовал в журнале "Egoist" (№ 4, декабрь 1917 г., с. 167) [Элиот 2011a], рассматривал роман «Накануне» (1860) именно в свете последних политических событий, что не случайно, учитывая дату публикации кни- 
ги. Гарнетт отмечал особое значение тургеневского романа для понимания современной политической ситуации: «Каковы бы ни были интересы Англии относительно России, лучше для нас понимать смысл устремлений России прежде, чем мы осознаем, какие силы мы можем применить против нее. И такой роман, как «Накануне», несмотря на его сорокалетний возраст, недальновидно считать устаревшим, так как он высвечивает отношение славянина к собственной политической судьбе» [Garnett 1917: 103]. Стоит заметить, что название «Накануне» довольно часто встречается в литературных опусах, связанных с революцией, например, так называется третья глава в книге Рида и его же «революционная виньетка» "On the Eve" (Рид был почитателем Тургенева, о чем писали наши литературоведы); такое же название дал Троцкий второй части своей книги «Литература и революция» [Троцкий 1991], перевод которой на английский вышел в том же 1925 г.

Вторая русская аллюзия, также связанная в европейском культурном сознании с темой революции, возникает в рассуждениях одного из героев рассказа Александра о знакомых анархистах. Он обращается к своей собеседнице Агате с такими словами: «Они - "капиталисты", потому что они живут за счет цивилизации, в которую они не внесли никакого вклада, и они - "анархисты”, потому что готовы уничтожить цивилизацию, которая их породила и выкормила. Конечно, есть определенная ирония в судьбе этих гадаринских свиней» [Eliot 1925: 279-280]. Отсылка к роману Ф.М. Достоевского «Бесы» (1871) связывает рассказ Элиота с традицией восприятия русского нигилизма на Западе, литературные корни которого выводили еще со времен О. Уайлда из романов Тургенева и Достоевского. Таким образом, название рассказа указывало на канун революционных событий, зачинщиками которых могли быть знакомые анархисты, готовые уничтожить цивилизацию: «...и все же единственный их интерес и развлечение - это развалить и разрушить Англию» [Eliot 1925: 279].

Изображая в ироническом свете и легкомысленном тоне фобии обывателя перед Фобосами революции, которая может разразиться в родных пенатах, Элиот вступает в диалог со своими современниками, обратившимися к этой же теме. Так, например, один из «русских» авторов “Criterion” Джон Курнос (John Cournos) еще в 1919 г. публикует в Лондоне небольшой двенадцатистраничный памфлет «Лондон под большевиками. Сон лондонца по возвращению из Петрограда» (London under the Bolsheviks. A London's Dream on Returning from Petrograd). Русский читатель знаком с этим эпизодом биографии Курноса по переводу романа Х.Д., Хильды Дулитл (Hilda Doolittle) «Вели мне жить» (Bid Me to Live, 
1960), в котором автор “Criterion" выведен под именем Ивана Левски: «Был еще Иван Левски, так и не вернувшийся из Петрограда, они часто вспоминали его, - собственно, из-за его комнаты все и началось, он оставил ее Белле, а сам укатил в Петроград переводить телефонограммы» (пер. Н. Рейнгольд) [Дулитл 2005, c. 227]. В своем памфлете Курнос переносит революционные события в Британию, чтобы английская аудитория смогла прочувствовать и представить действительность революционного времени. Во вступлении к тексту он поясняет: «Это не фантазия, несмотря на название. Это реальная и верная картина Петрограда в первые несколько месяцев после большевистской революции. Автор разместил сцены в Лондоне лишь для того, чтобы подчеркнуть реальность большевистского кошмара, донести его ужасы до тех, кто не совсем осознает природу русского переворота» [Cournos 1919: 2] ${ }^{3}$. Свои личные страхи и критическое отношение к событиям в России Курнос позднее выразил в серии публикаций в "Criterion".

Еще одну интересную параллель к «Накануне» представляет памфлет «Страх и политика. Дебаты в зоопарке» (Fear and Politics. A Debate at the Zoo, 1925) Леонарда Вулфа, имя которого также можно встретить на страницах “Criterion". Носорог-реакционер, мандрил-большевик, сова, слон, гиппопотам и другие обитатели зоопарка обсуждают современную политическую ситуацию, права человека и задачи пролетариата, Русскую и Французскую революции и т.п.; в их речах мелькают имена В.И. Ленина, Л.Д. Троцкого, А.И. Деникина, А.В. Колчака и др. Одним из вопросов, занимающих зверей, является проблема страха перед революцией и большевиками. Эту тему ставит в своей речи носорог: «Я бы хотел поговорить о русских или большевиках. Появление в мире этого нового вида животных, как и любое новое явление, вселяет ужас и порождает пророчества о катастрофе, к этому я могу только добавить, что полностью согласен с королем, графами Болдуинами, Нортумберлендами, Банбери, Пуанкаре, оплакиваемыми навечно царями и всеми другими консервативными видами человеческого рода, которые отказываются иметь что-либо общее и признавать право на существование этих ужасных творений» [Woolf 1993: 140].

Животные вступают в бурную полемику, высказывая самые разнообразные чувства по отношению к России и большевикам, дебаты разворачиваются в сатирическом ключе (так, больше-

${ }^{3}$ Полный текст памфлета в русском переводе Оскара Шейнина см. на сайте журнала-газеты «Мастерская»: http://club.berkovich-zametki.com/?p=2279 
вик-мандрил сообщает об исключительной окраске (“distinguished scheme of colouration”) Ленина и Троцкого) и завершаются философическими рассуждениями слона о том, что мир до тех пор будет одержим страхами, пока каждого человека не посадят в отдельную клетку. Рассказ Элиота «Накануне» занимает по своей политической ангажированности и серьезности тона промежуточную позицию между «контрреволюционером» Курносом и «социалистом» Вулфом. Вместе эти тексты дают представление о векторах и характере дискуссии по поводу угрозы и опасности Русской революции и большевизма для Британских островов и всего остального мира.

К концу 1920-х гг. журнальные материалы о Русской революции, большевизме и коммунизме принимают менее метафорический и более аналитический характер, что связано не только с образованием необходимой для осмысления временной дистанции, но и с массовым увлечением левыми идеями в Европе и США. В опубликованной в последнем выпуске "Criterion" редакторской колонке Элиот упоминает о резонансе дискуссий о коммунизме, проводившихся на страницах журнала: «В ретроспективе может показаться, что я посвятил слишком много внимания доктрине коммунизма как редактор и комментатор. Могу только заметить по этому поводу, что я всего лишь комментировал идеи или их отсутствие, а не занимался политическими пророчествами» [Eliot 1939: 272]. В своих редакционных комментариях Элиот неоднократно обращался к теме коммунизма (см. номера "Criterion" за апрель, июль 1932 г., январь, апрель, июль 1933 г., январь 1934 г., апрель 1935 г.).

Следует подчеркнуть, что Элиот в качестве редактора проявлял терпимость к противоположным политическим взглядам и давал возможность высказаться сторонникам самых разных идеологических течений. Так, в дискуссиях о коммунизме принимали участие как сторонники левых и либеральных идей (например, обсуждались взгляды основателя гильдейского социализма А.Дж. Пенти), так и представители консервативных и клерикальных кругов (К.Г. Доусон, В.А. Димант и др.). В журнале постоянно публиковались рецензии на книги о коммунизме, социализме, советском строе: «Коммунизм» лейбориста Г. Ласки, «Пособие по марксистской философии» христианского социалиста Дж. Льюиса, «Большевизм: теория и практика» американского политолога российского происхождения В. Гурьяна, «Красная Россия» немецкого национал-социалиста Т. Сайберта, «Советский коммунизм: новая цивилизация?» фабианцев С. и Б. Вебб и т.д. 
Довольно большое количество публикаций принадлежало таким сторонникам марксизма, как Альфред Лесли Роуз (Alfred Leslie Rowse, 1903-1997), Артур Лесли Мортон (Arthur Leslie Morton, 1903-1987) и др. Так, например, Мортоном, литературным критиком и историком, довольно хорошо известном отечественным исследователям по переводам его литературоведческих работ, в "Criterion" были опубликованы такие работы, как эссе «Поэзия и собственность в коммунистическом обществе» (Poetry and Property in a Communist Society, 1932) и многочисленные peцензии на книги, включая «Материализм и эмпириокритицизм» Ленина и «Портреты и памфлеты» Карла Радека.

Весьма активным автором “Criterion” был А.Л. Роуз, личность неординарная и эксцентричная, политик, поэт, специалист по елизаветинской литературе и У. Шекспиру, автор книги «Гомосексуалисты в истории» (из-под его пера вышло около ста книг на самые разнообразные темы). В журнале опубликованы такие его работы, как «Литература коммунизма: ее происхождение и теория» (The Literature of Communism: Its Origin and Theory, 1929); «Марксизм: ответ» (Marxism: A Reply, 1929); «Теория и практика коммунизма», (The Theory and Practice of Communism, 1930); «Эпос революции» (An Epic of Revolution, 1933) и др. Именно Роуз был рецензентом книги Троцкого «История русской революции» [Rowse 1933: 371-389]. В эссе «Литература коммунизма: ее происхождение и теория» Роуз, в частности, подчеркивает всемирное значении Русской революции: «Несомненным является то, что революция в России, как и большинство революций, высвободила огромной мощи психологическую и духовную энергию во всем мире» [Rowse 1929: 435]. В этой же работе Роуз, в частности, комментируя «Воспоминания о Ленине» Клары Цеткин, обращает внимание на гуманистические основы революционных преобразований в России: «Читая у Клары Цеткин описание семейной жизни Ленина, нельзя не почувствовать, что он, помимо прочих мотивов, был побуждаем стремлением делать добро для русского народа, чтобы увидеть его грамотным, сытым и свободным» [Rowse 1929: 435].

Именно статьи Роуза «Литература коммунизма: ее происхождение и теория» и «Фашизм» (Fascism) Джеймса Стрейчи Барнса (James Strachey Barnes, 1890-1955), британского теоретика фашизма, друга Б. Муссолини, опубликованные в апрельском номеpe "Criterion" за 1929 г., послужили поводом для написания уже упоминаемого эссе «Мистер Барнс и мистер Роуз». Впрочем, инициатором этой дискуссии был сам Элиот, разместивший в декабрьском номере за 1928 г. комментарий о литературе фашизма. 
Одним из главных тезисов работы «Мистер Барнс и мистер Роуз» является положение о сходстве доктрин коммунизма и фашизма. Элиот отмечает такие общие черты, как антикапиталистический пафос, популистский характер («понятность» идеи широким массам), «наполеонизм» (Ленин, Муссолини), материализм, «бестолковая» экономика ("the muddle of economics"), словесный энтузиазм ("enthusiasm for words") и т.п. Даже такие вроде бы полярные идеологические концепты, как «национализм» фашистов и «интернационализм» коммунистов, отражают, по мнению Элиота, схожее состояние умов: «...я не вижу фундаментальной разницы между национализмом и интернационализмом: и тот и другой термин может оказаться как пагубным, так и великолепным. Первый возвеличивает какую-то конкретную общность людей, другой (в теории) - все человечество; и ни одно из этих божеств мне не кажется заслуживающим особенного поклонения. Мудрые люди окажут должное уважение обоим, фанатики только одному» [Eliot 1929: 689]. Революция, как считает Элиот, должна свершиться, прежде всего, в сознании, на уровне идей, а фашизм и коммунизм не являются революционными идеями, эксплуатируя и трансформируя предшествующие социальные и культурные модели. Это суждение Элиота о «нереволюционности» фашизма и коммунизма непосредственно подтверждалось реальностью СССР, Италии, Германии, где подлинно революционные по характеру явления (искусство авангарда, например) вошли в противоречие с официальной идеологией и вкусами.

Непосредственным продолжением этой дискуссии стало эссе «Религия и тоталитарное государство» (Religion and the Totalitarian State) Кристофера Генри Доусона (Christopher Henry Dawson, 1889-1970). Доусон был автором не только близким по взглядам и духу редактору “Criterion”, но и мыслителем, в определённой степени оказавшим влияние на мировоззрение Элиота и становление его теории культуры (особенно тех аспектов, которые касались взаимодействию религии и культуры). В предисловии к трактату «Идея христианского общества» (The Idea of a Christian Socie$t y, 1939)$ Элиот отдает дань уважения своим предшественникам: «Однако многим я обязан ряду недавно появившихся книг: к примеру, таких, как “Превыше политики” м-ра Кристофера Доусона, “Цена лидерства" м-ра Мидлтона Марри, а также трудам преп. В.А. Диманта (чьи “Перспективы религии” появились слишком поздно, чтобы я мог ими воспользоваться). Я также глубоко обязан работам Жака Маритена, особенно его “Целостному гуманизму”» (пер. О.Я. Зоткиной) [Элиот 2004, с. 7]. Не сложно заметить, что Элиот приводит имена постоянных авторов журнала и участ- 
ников дискуссий о коммунизме и России, Рассмотрение его социокультурных работ 1930-1950-х гг. в контексте материалов "Criterion" делает очевидным тот факт, что Элиот впоследствии развивает многие идеи, высказанные и освоенные именно на страницах его журнала.

Доусона как религиозного философа интересуют, прежде всего, вопросы, связанные со взаимодействием церкви и государства, религии и культуры, веры и политики. Актуальным материалом для его размышлений является новая социокультурная реальность, возникшая и развивающаяся буквально на глазах - это новый тип тоталитарного государства. Доусон ставит ряд вопросов, ответы на которые он частично дает в своем эссе. Среди этих вопросов, в том числе, такие: «Какой должна быть позиция религиозного человека и религиозного сообщества в этих новых политических условиях? Насколько это новое политическое устройство угрожает духовной свободе, которая является неотъемлемой сущностью религии? Должна ли Церковь осудить тоталитарное государство само по себе и подготовиться к сопротивлению секулярной власти и преследованиям? Должна ли Церковь вступить в союз с теми политическими и социальными силами, которые враждебны новому государству? Или же должна ограничить сопротивление случаями вмешательства государства в церковные дела и теологические вопросы?» [Dowson 1934, p. 5]. Обращение к исследованию ситуации в Германии и России, отстраивающих новую политическую и культурную реальность закономерно с точки зрения взаимодействия религии и государства, проблемы старой, как мир (поднимаемой в литературе и философии с самого начала существования культурной европейской традиции, например, в «Антигоне» Софокла), но в данном случае Доусон пытается обнаружить новые формы взаимоотношения религии и тоталитарного общества. В отличие от Элиота, выявляющего сходство фашистской и коммунистической социальной теории, и практики, он пытается дифференцировать разные формы тоталитарного государства и типы его взаимодействия с церковью. В частности, он отмечает: «Все-таки коммунизм - это не просто форма политической организации; это экономический уклад, философия и вероучение ("a creed"). Его враждебность к христианству основана не столько на политической идеях, сколько на философии, на которой он базируется. Фактически коммунизм бросает вызов христианству на его собственной территории, предлагая человечеству конкурирующий путь спасения, - Или выражаясь словами коммунистического плаката, "Иисус пообещал людям рай после смерти, Ленин предлагает рай на земле”. Следовательно, антагонизм коммунизма и христианства основывается не на тоталитарном 
характере коммунистического государства, а на осознании религиозной исключительности коммунистической философии $[. .]$. [Dowson 1934: 7].

Любопытным представляется рассуждение Доусона о возможных причинах особенно жесткого характера борьбы с религией в России, обусловленных не только тоталитарным государственным устройством, а и предшествующей, дореволюционной традицией взаимодействия церкви и государства: «Довольно примечательно то, что процесс секуляризации отличается большей степенью жестокости в таких странах, как Россия, где церковь была тесно связана с государством и социальный конформизм играл большую роль в религии» [Dowson 1934: 15]. В заключение Доусон еще раз напоминает о том, что подлинная свобода возможна только в познании человеком Бога. Эссе Доусона переводит дискуссию о коммунизме в новое русло, его размышления носят универсальный характер, поэтому не случайны постоянные параллели с ситуацией в англо-саксонском мире, отсылки к истории, проповеднический пафос. Таким образом, вопросы о мессианстве коммунизма, его культовом характере, иррациональном начале, лежащем в основе реальной политики большевиков - одни из самых обсуждаемых в публикациях "Criterion".

К аналитическим оценкам коммунизма как доктрины и политической практики в “Criterion” обращались не только в связи с осмыслением опыта Русской революции и ее последствий. Объектом критики могли оказаться западные представители левых политических кругов. Так, например, в своем редакторском комментарии, опубликованном в 47-м номере за январь 1933 г., Элиот подвергает критике своих американских соотечественников, проповедующих «коммунистические подходы» к художественному творчеству. Комментарий был написан под впечатлением от поездки на родину (зимой 1932-1933 гг. Элиот находился в США в качестве «нортоновского» лектора в Гарвардском университете): «Пребывая в стране, где, по всей видимости, коммунистические идеи вошли в моду среди литераторов куда сильнее, чем в Англии, я просмотрел две книги, посвященные взаимосвязи литературы и социальных процессов. Одну из них нельзя назвать новой; перевод “Литературы и революции" Троцкого, впервые опубликованный в 1925 году, превратился сегодня в учебник по революционной литературе. Вторая книжка, “Освобождение американской литературы” м-ра Калвертона только что вышла из печати» [Элиот 2011б, с. 153].

Работы Троцкого стали выходить в Великобритании с 1918 г., Элиот же впервые обращается к критике Троцкого в «Коммента- 
рии» в январском номере "Criterion" за 1925 год, рецензируя работу «Вопросы быта» (английский перевод 1924 г.). Книга «Литература и революция» окажется для Элиота объектом пристального прочтения, он будет неоднократно обращаться к ней и в более поздних работах, например, в «Заметках к определению понятия “культура"» (1948). В целом, можно сказать, что Элиот оказался весьма внимательным читателем Троцкого и, несмотря на несовместимые политические позиции, не только с большой долей уважения относился как к содержанию, так и литературной форме трудов одного из главных действующих лиц Русской революции, но и творчески переработал ряд идей Троцкого, теоретика литературы революции. Определенная доля иронии, имеющаяся в комментариях редактора "Criterion", тем не менее, не мешает ему увидеть в подходах Троцкого к анализу «марксистской» литературы методологическую четкость и революционную «аутентичность»: «Троцкий, без сомнения, личность высокоинтеллектуальная, он выражает свои мысли при помощи резкого, метафорического стиля, и в том, что он утверждает, есть немало здравого смысла. Большая часть его книги посвящена критике авторов, которых я не читал, и которые, как я понимаю, никогда не переводились и вряд ли будут когда-либо переведены, но его трактат превосходен в качестве противоядия псевдореволюционному искусству» [Элиот 2011б, с.155].

Критика В.Ф. Калвертона (Victor Francis Calverton, 1900-1940), американского литератора марксисткой ориентации, издателя, в том числе, и работ Троцкого в США, отличается гораздо более суровым и саркастическим тоном. Его книга «Освобождение американской литературы» (The Liberation of American Literature, 1932) подвергается язвительному комментарию: «Марксист же обязан презирать удовольствия, даже такие скромные радости, которые можно получить при чтении эссе Эмерсона, и проводить свои дни в неусыпных трудах по выработке предписаний, каким следует быть искусству. Ступив на эту литературоведческую стезю, он должен направить свои силы не на постижение тайных и явных прелестей Гомера и Вергилия (из которых первый - личность весьма сомнительной идентичности и гражданства, а второй - льстивый прихвостень мелкобуржуазной империалистической династии), а на исполненный тяготами путь познания Эрнеста Хемингуэя и Джона Дос Пассоса, чтобы в конце этого нелегкого восхождения прийти к признанию высоких достижений Сэма Орница, Лестера Коэна, и Гренвилла Хикса» [Элиот 2011б, с. 158]. Как и в других работах, посвященных анализу коммунистической теории и практики, Элиот позиционирует себя в данном коммен- 
тарии как «христианского теоретика», уточняя при этом, что ценность произведения искусства не измеряется степенью его теологической или идеологической правильности. Он подвергает критике идею оценки произведения искусства с идейных, «апологетических» позиций: «Искусство, как нам видится, стремится к состоянию вневременного; а искусство коммунистическое, в соответствии с сентенциями его пророков, привязано к временному» [Элиот 20116, с. 157].

Все вышеупомянутые «русские» материалы имели достаточно широкий резонанс у просвещенной англоязычной публики, о чем можно судить по оценкам «русской деятельности» журнала, данной американским литературоведом Дороти Брюстер (Dorothy Brewster) в книге «Восточно-западный перевал: исследование литературных взаимосвязей» (East-West Passage: A Study in Literary Relationships, 1954). Несмотря на то, что автор явно не разделяет взглядов Элиота и направления редакторской политики, что выражается в иронической интонации по отношению к консервативным «критам» ('Crites') [Brewster 1954], Брюстер не может не признать их вклад в расширение представлений о русской культуре и советской действительности. В качестве образца ее саркастических выпадов можно привести пассаж, характеризующий элиотовские рецензии Троцкого, отличающийся большой плотностью и исторической конкретностью культурных символов и в целом отражающий сложный состав идеологической смеси, «пыли эпохи», которая частично оседает в лабиринтах коллективной памяти: «Балет на жерле извергающегося вулкана - несомненно тот образ новой России, который бы утолил жажду “критов” на бесплодной земле» [Brewster 1954: 183]. Также, хотя автор и продолжает держать ироническую ноту в отношении «критов», Брюстер, касаясь дискуссии Элиота и Роуза, не может не признать, что из материалов в “Criterion", который, на первый взгляд, был весьма неподходящим местом для такого рода публикаций, читатель мог получить вполне достоверную и «надежную информацию» о России [Brewster 1954: 184].

В рамках обсуждаемой темы нельзя пройти мимо маленькой крайтерионовской «Ленинианы», которая включает уже упомянутую рецензию Мортона на книгу «Материализм и эмпириокритицизм, его же рецензию на издание писем Ленина (Nilolai Lenin “Letters”) в июльском номере за 1937 г., стихотворение Х. МакДиармида (Hugh McDiarmid) «Второй гимн Ленину» (Second Hymn to Lenin) в июльском номере за 1932 г. и эссе Курноса «Сотворение мифа» (Myth in Making) в январском номере за 1934 г. Тема культа Ленина в СССР поднималась во многих публикациях 
журнала, в том числе и в уже упомянутых в этой статье, однако эссе Курноса полностью посвящено этой теме. Курнос в самом начале текста, процитировав слова советской писательницы Лидии Сейфуллиной о том, что советские писатели не признают творчества, отделенного от политики, поясняет западному читателю, что смысл слова «политика» в СССР отличается от того, который вкладывают в него британцы. К этому Курнос добавляет, что одним из основных источников вдохновения советских писателей является Ленин как «животворящая сила, символ энергии и оптимизма» [Cournos 1934: 226].

В качестве иронической культурно-исторической параллели Курнос обращается к греческой мифологии, подвигам троянских героев и т.п. Античные аналогии дополняет информация о портретах Ленина, висящих рядом с иконами в русских крестьянских избах, орденах Ленина, которыми награждают рабочих-передовиков и т.п. Автор сокрушается, что никакому Гомеру не под силу воспеть деяния Ленина или события, произошедшие в 1917 г., а потому Ленин вынужден предстать фольклорным героем: «у нас есть уникальная возможность быть свидетелями формирования на советском Востоке процесса того, как Ленин становится не просто частью истории, не просто частью легенды, а сам превращается в миф, обладающий всей магией мифа, способного воодушевить на песенное творчество самого последнего бедняка, часто неграмотного, иногда даже слепого» [Cournos 1934: 227]. Курнос информирует западного читателя о появлении многочисленных советских сказителей-«аэдов» (ашугов, бахши, хафизов), несущих свои песни «от кишлака к кишлаку», «от деревни к деревне»: «Эти рапсоды поют об электрификации, новых тракторах, ирригации, Октябрьской революции, но, прежде всего, они воспевают Ленина» [Cournos 1934: 228]. И хотя после своей последней поездки в 1917-1918 гг. Курнос больше никогда не посещал советскую Россию, надо отдать должное его осведомленности о событиях, происходящих на исторической родине. Свои, не лишенные комизма, тезисы и рассуждения он подкрепляет фактическим материалом, в качестве наглядной иллюстрации, приводит тексты киргизской (a Kirghiz song) и узбекской (a Ferghana folk song) народных песен о Ленине в английском переводе: «Many are we on this earth set free by Lenin // Uzbeks, Urus, Tadjiks, and other peoples, // All of us have in our blood, a drop of Lenin's blood, // And we will defend our freedom» [Cournos 1934: 229].

В целом, именно Курнос становится в “Criterion” основным «поставщиком» материалов о современной повседневной и культурной жизни в Советском Союзе. Два других «русских» «крита», 
Самуил Соломонович Котелянский и Дмитрий Петрович Святополк-Мирский, занимали несколько иные ниши в журнале: публикации Котелянского были в основном посвящены классической русской литературе, а диапазон тем, связанных с «Д.С.» Мирским, был довольно широк, что объяснялось широтой натуры и интересов самого князя-коммуниста. Если о жизни и литературной деятельности Котелянского и Мирского в последнее время пишут довольно активно (в рамках данной темы хотелось бы отметить публикации О.А. Казниной, в частности, ее книгу «Русские в Англии. Русская эмиграция в контексте русско-английских литературных связей в первой половине XX века» [Казнина 1997]), то с творчеством Курноса отечественная аудитория практически не знакома.

Джон Курнос (1881-1966; настоящее имя - Иван Григорьевич Коршун), уроженец Житомира, вместе с семьей эмигрировавший в США в 1891 г., заслуживает большего внимания со стороны как историков, филологов, так, возможно, и беллетристов. Писатель, переводчик, публицист, культурный и общественный деятель, личность авантюрного склада, чье имя всплывает в самых разнообразных культурных контекстах — от группы Блумсбери и имажистов до Комитета освобождения России и романа Дороти Сэйерс «Сильный яд», сыграл значительную роль в популяризации русской и советской литературы в англоязычном мире. Курнос переводил Андрея Белого, Ф. Соллогуба, И. Бабеля, рассказы советских писателей (short stories out of Soviet Russia) и др. ${ }^{4}$

Курнос был автором самых разнообразных публикаций в журнале “Criterion”: эссе, книжных рецензий, обзоров периодических изданий. Так, например он являлся рецензентом книг, посвященных советской России: «Новая Россия» (New Russia) А. де Монзи (A. de Monzie); «Русский окольный путь: неполитическое паломничество» (Russian Roundabout: A Non-Political Pilgrimage) А. Лайолла (A. Lyall); «Русские умы в оковах» (Russian Minds in Fetters) C. Мацкевича (S. Mackiewicz); «Молодежь в советской России» (Youth in Soviet Russia) К. Менерта (K. Mehnert); «Россия: социальная история» (Russia: A Social History) Д.П. Мирского (D.S. Mirsky); «Зима в Москве» (Winter in Moscow) М. Маггериджа (M. Muggeridge); «Красная Россия» (Red Russia) Т. Сайберта (Seibert T.) и др.

Особый интерес представляют его публикации, связанные с хроникой советской культурной жизни и обзорами русскоязычной

${ }^{4} \mathrm{O}$ его переводческой деятельности см. статью американской исследовательницы М. Швин-Смит «Английские переводы Ремизова: новые материалы» [Schwinn Smith 2012]. 
периодики (“Russian periodicals”) в специальном разделе журнала «Обзоры зарубежной периодики» (“Foreign Reviews”). Следует отметить уникальность этого явления. Подробнейшие обзоры советской периодики Курноса составляют в совокупности ценный материал, остающийся актуальным по сей день, что было отмечено авторами, обращавшимися к этой теме. Так, Дэвид Эйрз в своей статье, посвященной литературной деятельности Курноса в "Criterion", даже выражает сожаление, что в журнале не было аналогичных обзоров британской периодики того времени и отмечает высокое качество материалов и объективность позиции самого Курноса: «Его литературный опыт, лингвистические способности, его важное, хотя и ограниченное временем, знакомство с реальностью Русской революции и его постоянный напряженный интерес к развитию русской литературной жизни, даже несмотря не то, что сам он избрал своим поприщем английскую литературную сцену, все эти факторы сделали его идеальным медиатором между миром советской литературы и страницами "Criterion”. Избегая пропагандистских антикоммунистических идеологических выпадов и одновременно не находясь под влиянием советской пропаганды, которого не избежали многие знаменитые писатели, Курнос доходчиво повествовал о современной русской литературе, в то время, как эмигрантские круги теряли к ней интерес, а советские литераторы стали жертвами прямого политического контроля» [Ayers (b) 2011: 367]. Ту же высокую степень объективности и дотошность, присущую обзорам Курноса, отмечает такой строгий критик «Criterion» как Дороти Брюстер, с воодушевлением перечисляя имена авторов, рецензируемых в журнале: Маяковский, Иванов, Леонов, Катаев, Алексей Толстой, Фадеев, Пастернак, Гладков, Лидин, Пришвин [Brewster 1954: 184].

Курнос делает подробнейшие обзоры таких советских периодических изданий, как «Новый мир», «Красная новь», «Октябрь», «Литературный критик», «Прожектор», «Литературная газета» и т.д. Он сообщает читателям о новостях литературной жизни, поясняет детали хитросплетений советского литературного была, рассказывает о партийных постановлениях, конференциях, новинках советской литературы и т.п. Так, в октябрьском номере "Criterion" за 1936 г. Курнос обстоятельно анализирует публикации журналов «Литературный критик», «Октябрь» и «Литературной газеты». Курнос дает общую характеристику изданию (например, про «ЛГ» он сообщает, что «это орган Союза советских писателей, выходит два раза в неделю на шести газетных полосах» [Cournos 1936: 203]), далее следует подробный анализ публикуемых материалов с цитированием, пояснением специфических реалий и т.п. 
Создается впечатление, что самому Курносу необычайно интересно то, о чем он рассказывает, не случайно обзор завершается выводом о том, что «Россия всегда была страной литературной борьбы. И сейчас она даже проходит несколько оживленнее, чем обычно» [Cournos 1936: 204]). Только из упомянутого обзора Курноса читатель мог узнать о полемике вокруг формализма и натурализма в газете «Правда», стахановцах, работе Д. Лукача «Интеллектуальный облик литературного героя», В.Г. Белинском и Н.А. Добролюбове, статье В.Я. Кирпотина «Литература и советский народ», смерти Максима Горького, сталинском определении социалистического реализма, реконструкции площади Маяковского, обличениях советскими критиками «Улисса» Дж. Джойса и т.п.

Эссе Курноса «Русская хроника. Советская Россия и литература идей» (Russian Chronicle. Soviet Russia and the Literature of Ideas) было опубликовано в первой части январского номера журнала «Criterion» за 1935 г. Сам факт того, что работа, посвященная обзору культурной жизни в СССР, размещена в том разделе журнала, где обычно печатались художественные тексты (поэзия самого редактора, например), статьи фундаментального характера, говорит о том, что тема и автор были интересны читателю. Эссе начиналось с провокативного заявления: «Однажды какой-нибудь проницательный критик, возможно, напишет историю русской литературы, подробно проанализировав, начавшийся в 1880 году процесс ее постепенного и неуклонного упадка, который, несомненно, был приостановлен революцией, но в то же время ею же и ускорен» [Cournos 1935: 283]. Основным объектом критики становится литература социалистического реализма: «От старых привычек избавиться трудно, будь они буржуазные или коммунистические. Что случится, если избавляться от них в литературном творчестве? Со спокойной совестью можно утверждать, что, все, что было хорошего в литературе Советской России в последние годы - я имею в виду такие имена, как Бабель, Пастернак, Шолохов, Леонов, Иванов, Алексеев и др. - все это относится скорее к старой, чем к новой литературе, к традиции, а не к коммунизму» [Cournos 1935: 290].

Это эссе, как и другие работы Курноса, отличает хорошее знание материала и саркастический тон при описании политической ангажированности советских литераторов. В частности, Курнос не без иронии цитирует высказывания о Шекспире редактора «Интернациональной литературы» С.С. Динамова. Несомненно, работа Курноса в качестве автора "Criterion" и обозревателя советской культуры заслуживает большего внимания со стороны отечественных исследователей, так как представляет нетри- 
виальный, «иной» взгляд на процессы, происходившие в России после революции.

Подведя итог нашему краткому обзору публикаций о Русской революции и ее контекстах в журнале “Criterion” (за рамками статьи осталось еще немало интересного материала), можно с большой долей уверенности рекомендовать элиотовское детище в качестве ценного ресурса для изучения интеллектуальной и социально-политической панорамы своего времени. Тема Русской революции в журнале представлена широким спектром оценок и откликов разной политической и культурной направленности, без навязывания читателю единственной точки зрения, что побуждает пристальнее всмотреться в те исторические события, столетнюю годовщину которых мы нынче отмечаем и лучше понять феномен революции во всей его сложности и противоречивости. Не к этому ли побуждал читателей герой крайтерионовских публикаций и автор «Истории русской революции», рецензируемой в журнале: «Нет ничего более жалкого, как морализирование по поводу великих социальных катастроф! Здесь особенно уместно правило Спинозы: не плакать, не смеяться, а понимать» [Троцкий 1997, с. 25].

\section{ЛИТЕРАТУРА}

[Дулитл 2005] - Дулитл X. Вели мне жить. Мадригал. М.: Б.С.Г.-ПРЕСС, 2005.

[Казнина 1997] - Казнина O.А. Русские в Англии. Русская эмиграция в контексте русско-английских литературных связей в первой половине XX века. М.: Наследие, 1997.

[Крупская 1987] - Крупская Н.К. Предисловие к русскому изданию // Рид Дж. Десять дней, которые потрясли мир. Вильямс А.-Р. Путешествие в революцию. М.: Худож. лит., 1987. С. 28-29.

[Либман 1977] - Либман В.Я. Американская литература в русских переводах и критике. Библиография 1776-1975. М.: Наука, 1977.

[Пайман 1993] - Пайман А. Блок в английском и американском литературоведении // Литературное наследство. М.: Наука, 1993. Т. 92, кн. 5. С. 362-401.

[Троцкий 1997] - Троцкий Л.Д. История русской революции: В 2 т. Т. 1. М.: ТЕРРА; Республика, 1997.

[Троцкий 1991] — Троикий Л.Д. Литература и революция. М.: Политиздат, 1991.

[Ушакова 2016] - Ушакова О.М. Русский нигилист как герой английской литературы XIX-XXI вв. // Вестник Пермского университета. Российская и зарубежная филология. 2016. № 1. С. 106-117.

[Ушакова 2011] - Ушакова О.М. Т.С. Элиот - издатель: Россия и русская культура на страницах журнала «Крайтерион» // Отображение и интерпретация истории в культуре США. Материалы XXXIV Международной конференции Российского общества по изучению культуры США 12-17 декабря 2008. М.: Факультет журналистики МГУ, 2011. С. 295-302.

[Ушакова 2014] - Ушакова О.М. Ф.М. Достоевский и Т.С. Элиот: формы репрезентации и парадоксы интерпретации // Литературоведческий журнал. 2014. № 34. C. $35-49$. 
[Элиот 1971] - Элиот Т.С. Бесплодная земля. М.: Прогресс, 1971.

[Элиот 2014] - Элиот T.С. Бесплодная земля. М.: Ладомир: Наука, 2014.

[Элиот 2004] - Элиот Т.С. Избранное. Т. I-II. Религия, культура, литература. М.: РОССПЭН, 2004.

[Элиот 2011б] - Элиот Т.С. Комментарий // Вестник Православного Свято-Тихоновского гуманитарного университета. Серия 3: Филология. 2011. № 1 (23). С. 153158.

[Элиот 2011a] - Элиот Т.С. Тургенев // Вестник Православного Свято-Тихоновского гуманитарного университета. Серия 3: Филология. 2011. № 1 (23). С. 151-153.

[Ayers (a) 2011] — Ayers, David. "The Criterion and Communism." Otobrazhenie $i$ interpretacija istorii v kul'ture SShA. Materialy XXXIV Mezhdunarodnoj konferencii Rossijskogo obshhestva po izucheniju kul'tury SShA 12-17 dekabrja 2008. Moscow, Fakul'tet zhurnalistiki MGU publ., 2011: 304-312.

[Ayers (b) 2011] - Ayers, David. "John Cournos and the Politics of Russian Literature in The Criterion.” Modernism/Modernity XVIII (2 Apr. 2011): 355-369.

[Blok 1920] - Blok, Alexander. The Twelve. London, Chatto \& Windus, 1920.

[Bowra 1932] - Bowra, C.M. "The Position of Alexander Blok." [The Criterion XI: 44 (Apr. 1932)]. The Criterion. The Collected Edition. Vol. XI. London: Faber and Faber Ltd., 1967: 422-438.

[Brewster 1954] — Brewster, Dorothy. East-West Passage: A Study in Literary Relationships. London: G. Allen \& Unwin, 1954.

[Cournos 1919] - Cournos, John. London under the Bolsheviks. A London's Dream on Returning from Petrograd. London: Russian Liberation Committee, 1919.

[Cournos 1934] - Cournos, John. "Myth in Making." [The Criterion XIII: 51 (Jan 1934)]. The Criterion. The Collected Edition. Vol. XIII. London: Faber and Faber Ltd., 1967: 225-229.

[Cournos 1935] - Cournos, John. "Russian Chronicle. Soviet Russia and the Literature of Ideas." [The Criterion XIV: 55 (Jan. 1935)]. The Criterion. The Collected Edition. Vol. XIV. London: Faber and Faber Ltd., 1967: 283-291.

[Cournos 1936] - Cournos, John. "Russian Periodicals." [The Criterion XIII: 62 (Oct. 1936)]. The Criterion. The Collected Edition. Vol. XIII. London: Faber and Faber Ltd., 1967: 195-204.

[Dowson 1934] - Dowson, Christopher H. "Religion and the Totalitarian State." [The Criterion XIV: 54 (Oct. 1934)]. The Criterion. The Collected Edition. Vol. XIV. London: Faber and Faber Ltd., 1967: 1-16.

[Eliot 1927] — Eliot, T.S. "A Commentary." [The Criterion VI: 2 (Aug. 1927)]. The Criterion. The Collected Edition. Vol. VI. London: Faber and Faber Ltd., 1967: 97-100.

[Eliot 1929] — Eliot, T.S. "Mr. Barnes and Mr. Rowse." [The Criterion VIII: 33 (Jul. 1929)]. The Criterion. The Collected Edition. Vol. VIII. London: Faber and Faber Ltd., 1967: 682-691.

[Eliot 1939] — Eliot, T.S. "The Last Words." [The Criterion XVIII: 71 (Jan. 1939)]. The Criterion. The Collected Edition. Vol. XVIII. London: Faber and Faber Ltd., 1967: 269-275.

[The Letters of T.S. Eliot 2009] - Eliot, T.S. Letter to Stanley Rice (October 1, 1923). The Letters of T.S. Eliot. Vol. 2 (1923-1925). New Haven; London: Yale University Press, 2009.

[Eliot 1925] - Eliot, T.S. "On the Eve. A Dialogue." [The Criterion III: 10 (Jan. 1925)]. The Criterion. The Collected Edition. Vol. III. London: Faber and Faber Ltd., 1967: 278-281.

[Eliot 1967] - Eliot, T.S. "Preface." The Criterion. The Collected Edition. Vol. I. London: Faber and Faber Limited, 1967: i. 
[Garnett 1917] — Garnett, Edward. Turgenev. A Study. London: W. Collins Sons \& Co. Ltd., 1917.

[Koteliansky Papers 1917] — "Hail! The Russian Revolution. Message from British Socialists. 3 June 1917.” Koteliansky Papers. Vol. IX. Add. 48974. File 13. The British Library Manuscript Collections. The British Library.

[Rowse 1933] — Rowse, Alfred L. "An Epic of Revolution.” [The Criterion XIII: 48 (Apr. 1933)]. The Criterion. The Collected Edition. Vol. XIII. London: Faber and Faber Ltd., 1967: 371-389.

[Rowse 1929] - Rowse, Alfred L. "The Literature of Communism: Its Origin and Theory." [The Criterion VIII: 32 (Apr. 1929)]. The Criterion. The Collected Edition. Vol. VIII. London: Faber and Faber Ltd., 1967: 278-281.

[Schwinn Smith 2012] - Schwinn Smith, Marilyn. "Aleksei Remizov's Englishlanguage Translators: New Material." A People Passing Rude: British Responses to Russian Culture, ed. by Anthony Cross. Cambridge: Open Book Publishers, 2012: 191-202.

[Seymour-Jones 2002] — Seymour-Jones, Carole. Painted Shadow. New York; London; Toronto; Sydney; Auckland: Nan A. Talese: Doubleday, 2002.

Ushakova, Olga. "Russia and Russian Culture in "The Criterion", 1922-1939." A People Passing Rude: British Responses to Russian Culture, ed. by Anthony Cross. Cambridge: Open Book Publishers, 2012: 231-240.

[The Waste Land 1971] — The Waste Land: A Facsimile and Transcript of the Original Drafts, Including the Annotations of Ezra Pound. San Diego; New York; London: A Harvest Book: Harcourt, INC, 1971.

[Woolf 1993] — Woolf, Leonard. "Fear and Politics." A Bloomsbury Group Reader, ed. by Rosembaum S.P. Oxford, UK \& Cambridge, MA: Blackwell, 1993: 136-151.

\section{REFERENCES}

Ayers, David. "The Criterion and Communism." Otobrazhenie i interpretacija istorii $v$ kul'ture SShA. Materialy XXXIV Mezhdunarodnoj konferencii Rossijskogo obshhestva po izucheniju kul'tury SShA 12-17 dekabrja 2008. Moscow: Fakul'tet zhurnalistiki MGU publ., 2011: 304-312.

Ayers, David. "John Cournos and the Politics of Russian Literature in The Criterion." Modernism/Modernity XVIII (2 Apr. 2011): 355-369.

Blok, Alexander. The Twelve. London: Chatto \& Windus, 1920.

Bowra, C.M. "The Position of Alexander Blok." [The Criterion XI: 44 (Apr. 1932)]. The Criterion. The Collected Edition. Vol. XI. London: Faber and Faber Ltd., 1967: 422438.

Brewster, Dorothy. East-West Passage: A Study in Literary Relationships. London: G. Allen \& Unwin, 1954.

Cournos, John. London under the Bolsheviks. A London's Dream on Returning from Petrograd. London: Russian Liberation Committee, 1919.

Cournos, John. "Myth in Making." [The Criterion XIII: 51 (Jan. 1934)]. The Criterion. The Collected Edition. Vol. XIII. London: Faber and Faber Ltd., 1967: 225-229.

Cournos, John. "Russian Chronicle. Soviet Russia and the Literature of Ideas." [The Criterion XIV: 55 (Jan. 1935)]. The Criterion. The Collected Edition. Vol. XIV. London: Faber and Faber Ltd., 1967: 283-291.

Cournos, John. "Russian Periodicals." [The Criterion XIII: 62 (Oct. 1936)]. The Criterion. The Collected Edition. Vol. XIII. London: Faber and Faber Ltd., 1967: 195-204.

Dowson, Christopher H. "Religion and the Totalitarian State." [The Criterion XIV: 54 (Oct. 1934)]. The Criterion. The Collected Edition. Vol. XIV. London: Faber and Faber Ltd., 1967: 1-16. 
Dulitl, H. Veli mne zhit'. Madrigal. Moscow: B.S.G.-PRESS Publ., 2005.

Eliot, T.S. Besplodnaja zemlja. Izbrannye stihotvorenija i pojemy, transl. A. Sergeev. Moscow: Progress Publ., 1971.

Eliot, T.S. Besplodnaja zemlja. Moscow: Ladomir; Nauka Publ., 2014.

Eliot, T.S. "A Commentary." [The Criterion VI: 2 (Aug. 1927)]. The Criterion. The Collected Edition. Vol. VI. London: Faber and Faber Ltd., 1967: 97-100.

Eliot, T.S. Izbrannoe. V. I-II. Religija, kul'tura, literatura. Moscow: ROSSPEN Publ., 2004.

Eliot, T.S. Kommentarij. Vestnik Pravoslavnogo Svjato-Tihonovskogo gumanitarnogo universiteta. Serija 3: Filologija 1/23 (2011): 153-158.

Eliot, T.S. "The Last Words." [The Criterion XVIII: 71 (Jan. 1939)]. The Criterion. The Collected Edition. Vol. XVIII. London: Faber and Faber Ltd., 1967: 269-275.

Eliot, T.S. Letter to Stanley Rice (October 1, 1923). The Letters of T.S. Eliot. Vol. 2 (1923-1925). New Haven; London, Yale University Press, 2009.

Eliot, T.S. "Mr. Barnes and Mr. Rowse." [The Criterion VIII: 33 (Jul. 1929)]. The Criterion. The Collected Edition. Vol. VIII. London: Faber and Faber Ltd., 1967: 682-691.

Eliot, T.S. "On the Eve. A Dialogue." [The Criterion III: 10 (Jan. 1925)]. The Criterion. The Collected Edition. Vol. III. London: Faber and Faber Ltd., 1967: 278-281.

Eliot, T.S. "Preface." The Criterion. The Collected Edition. Vol. I. London: Faber and Faber Limited, 1967: i.

Eliot, T.S. Turgenev. Vestnik Pravoslavnogo Svjato-Tihonovskogo gumanitarnogo universiteta. Serija 3: Filologija 1/23 (2011): 151-153.

Garnett, Edward. Turgenev. A Study. London: W. Collins Sons \& Co. Ltd., 1917.

"Hail! The Russian Revolution. Message from British Socialists. 3 June 1917." Koteliansky Papers. Vol. IX. Add. 48974. File 13. The British Library Manuscript Collections. The British Library.

Kaznina, O.A. Russkie v Anglii. Russkaja jemigracija v kontekste russko-anglijskih literaturnyh svjazej v pervoj polovine XX veka. Moscow: Nasledie Publ., 1997.

Krupskaja, N.K. Predislovie k russkomu izdaniju. Rid Dzh. Desjat' dnej, kotorye potrjasli mir. Vil'jams A.-R. Puteshestvie v revoljuciju. Moscow: Hudozh. lit. Publ., 1987: $28-29$.

Libman, V.Ja. Amerikanskaja literatura v russkih perevodah i kritike. Bibliografija 1776-1975. Moscow: Nauka Publ., 1977.

Pajman, A. Blok v anglijskom i amerikanskom literaturovedenii. Literaturnoe nasledstvo. Moscow: Nauka Publ., 1993. T. 92, kn. 5: 362-401.

Rowse, Alfred L. “An Epic of Revolution.” [The Criterion XIII: 48 (Apr. 1933)]. The Criterion. The Collected Edition. Vol. XIII. London: Faber and Faber Ltd., 1967: 371-389.

Rowse, Alfred L. "The Literature of Communism: Its Origin and Theory." [The Criterion VIII: 32 (Apr. 1929)]. The Criterion. The Collected Edition. Vol. VIII. London: Faber and Faber Ltd., 1967: 278-281.

Schwinn Smith, Marilyn. "Aleksei Remizov's English-language Translators: New Material." A People Passing Rude: British Responses to Russian Culture, ed. by Anthony Cross. Cambridge: Open Book Publishers, 2012: 191-202.

Seymour-Jones, Carole. Painted Shadow. New York; London; Toronto; Sydney; Auckland: Nan A. Talese: Doubleday, 2002.

Trockij, L.D. Istorija russkoj revoljucii: V 2 t. T. 1. Moscow: TERRA; Respublika Publ., 1997.

Trockij, L.D. Literatura i revoljucija. Moscow: Politizdat Publ., 1991.

Ushakova, O.M. F.M. Dostoevskij i T.S. Eliot: formy reprezentacii i paradoksy interpretacii. Literaturovedcheskij zhurnal 34 (2014): 35-49. 
Ushakova, Olga. "Russia and Russian Culture in "The Criterion", 1922-1939." A People Passing Rude: British Responses to Russian Culture, ed. by Anthony Cross. Cambridge: Open Book Publishers, 2012: 231-240.

Ushakova, O.M. Russkij nigilist kak geroj anglijskoj literatury XIX-XXI vv. Vestnik Permskogo universiteta. Rossijskaja i zarubezhnaja filologija 1 (2016): 106-117.

Ushakova, O.M. T.S. Eliot - izdatel': Rossija i russkaja kul'tura na stranicah zhurnala" Krajterion”. Otobrazhenie i interpretacija istorii v kul'ture SShA. Materialy XXXIV Mezhdunarodnoj konferencii Rossijskogo obshhestva po izucheniju kul'tury SShA 12-17 dekabrja 2008. Moscow: Fakul'tet zhurnalistiki MGU, 2011: 295-302.

The Waste Land: A Facsimile and Transcript of the Original Drafts, Including the Annotations of Ezra Pound. San Diego; New York; London: A Harvest Book; Harcourt, INC, 1971.

Woolf, Leonard. "Fear and Politics." A Bloomsbury Group Reader, ed. by Rosembaum S.P. Oxford, UK \& Cambridge, MA: Blackwell, 1993: 136-151. 